Kostas Tsigaridis ${ }^{1,2}$ and Maria Kanakidou ${ }^{3}$

\title{
The present and future of secondary organic aerosol direct forcing on climate
}

\author{
${ }^{1}$ Center for Climate Systems Research, Columbia University, 2880 Broadway, New York, NY 10025, USA. \\ ${ }^{2}$ NASA Goddard Institute for Space Studies, 2880 Broadway, New York, NY 10025, USA. \\ ${ }^{3}$ Environmental Chemical Processes Laboratory, Department of Chemistry, University of Crete, P.O.Box \\ 2208, 70013 Heraklion, Greece.
}

Corresponding author: kostas.tsigaridis@columbia.edu, +1 (212) 678-5668.

ORCID IDs: KT: 0000-0001-5328-819X; MK: 0000-0002-1724-9692.

\begin{abstract}
Secondary organic aerosols (SOA), a subset of organic aerosols that are chemically produced in the atmosphere, are included in climate modeling calculations using very simple parameterizations. Estimates on their shortwave forcing on climate span almost two orders of magnitude, being potentially comparable to sulfate direct forcing. In the longwave, a neglected part of the spectrum when it comes to SOA, the direct SOA forcing could exceed that of sulfate and black carbon, although in absolute values it is much weaker than the shortwave forcing. Critical for these estimates is the vertical distribution of the climate active agents, pointing to SOA temperature-dependent volatility. Over the last few years, research also revealed the highly oxidized character of organic aerosol and its chemical aging in the atmosphere that partially leads to the formation of brown carbon, an absorbing form of organic aerosol. This review summarizes critical advances in the understanding of SOA behavior and properties relevant to direct climate forcing and puts them in perspective with regard to primary organic aerosol and brown carbon. These findings also demonstrate an emerging dynamic picture of organic aerosol that has not yet been integrated in climate modeling. The challenges for the coming years in order to reduce uncertainties in the direct organic aerosol climate impact are discussed. High priority for future model development should be given to the dynamic link between "white" and "brown" organic aerosol and between primary and secondary organic aerosol. The SOA temperature-dependent volatility parameterizations and wavelength-dependent refractive index should be also included.
\end{abstract}

\section{Keywords}

Secondary organic aerosols; aerosol radiative forcing; brown carbon, aerosol direct effect; aerosol aging 


\section{Acknowledgments}

Climate modeling at Goddard Institute for Space Studies (GISS) is supported by the National Aeronautics and Space Administration (NASA) Modeling, Analysis, and Prediction (MAP) program. Resources supporting this work were provided by the NASA High-End Computing (HEC) Program through the NASA Center for Climate Simulation (NCCS) at Goddard Space Flight Center (GSFC). KT acknowledges support from NASA MAP, contract NNX09AK32G, and Atmospheric Composition Modeling and Analysis Program (ACMAP), contract NNX15AE36G. MK acknowledges support by the European FP7 collaborative project BACCHUS (Impact of Biogenic versus Anthropogenic emissions on Clouds and Climate: towards a Holistic UnderStanding), European Commission Framework Program 7, FP7-ENV-2013, grant agreement number 603445.

On behalf of all authors, the corresponding author states that there is no conflict of interest. 


\section{Introduction}

During the last two decades our understanding of organic aerosols (OA) and their role on atmospheric composition has advanced with explosive rates, thanks to advances in both laboratory and field work. This is particularly true for the case of secondary OA (SOA), which is formed in the atmosphere by processes like chemical oxidation. Already from the 1990s it was known that SOA can form from the oxidation of anthropogenically-emitted aromatic compounds [1, 2], as well as biogenically-emitted hydrocarbons like monoterpenes [3], and other reactive volatile organic compounds (VOCs) emitted by vegetation [4]. Isoprene was not yet identified as an important SOA precursor [5] due to the high volatility of its products and the very low aerosol yields at the conditions of laboratory experiments [6, 7]. However, the large isoprene emissions on the global scale [8] imply that even a small yield can form substantial amounts of aerosol [9]. Simplified parameterizations to calculate the partitioning of the oxidation products of the parent VOCs and the subsequent formation of SOA have been developed [10,11] and started to be used in global models [12-14], including studies of the preindustrial [15] and future atmospheres [16].

SOA formation simulations are characterized by very large physicochemical uncertainties and computationally intensive calculations, therefore most global models were forced to adopt a simple parameterization to calculate SOA atmospheric distribution. The SOA formation in the atmosphere from precursor VOCs was emulated by an emission-like yield, with the produced SOA considered non-volatile, resulting in direct SOA emissions in the particulate phase, similarly to primary OA (POA) [17]. Regardless of whether models included a parameterization of semi-volatile SOA or the simplified flux-based approach of non-volatile SOA, in the mid-2000s there was enough information available to model SOA occurrence on the global scale [9], which led to a number of different parameterizations of various complexities introduced in chemistry/transport models (CTMs). Even until now though, a substantial fraction of global models still use the simplified SOA parameterization [18].

During the last decade the importance of OA, including SOA, in atmospheric aerosol composition has been widely acknowledged. Numerous field campaigns worldwide revealed that OA are ubiquitous in the atmosphere, with most of them being oxygenated, which largely means secondary in nature $[19,20]$. Besides mechanisms known to form SOA from gaseous precursors and the chemical aging of POA, a wealth of new SOA formation mechanisms have been identified, including oligomerization and fragmentation that drastically modify the volatility of SOA components $[20,21]$. These have been thoroughly reviewed in the recent literature [21]. The general underestimation of urban SOA in models [22] has been reduced in more recent model simulations with sophisticated treatment of OA aging, volatility and precursor molecules [23]. Surprisingly, on the global scale no noticeable improvement of skill was found between models with the simple flux parameterization and others with more sophisticated SOA treatments [18] when comparing against measurements, pointing to missing sources and/or processes from models.

In a seminal review a little over a decade ago [9], the global SOA source was estimated to range between 12 and $70 \mathrm{Tg} \mathrm{a}^{-1}$, a range that comes almost exclusively from biogenic SOA. That estimate overlaps with more recent evaluations of a global biogenic SOA source of $88 \mathrm{TgC}^{-1}$ [24] and 21.5 to 99.3

$\mathrm{Tg} \mathrm{a}^{-1}$ [25], which increases to 36.2-132.2 $\mathrm{Tg} \mathrm{a}^{-1}$ when taking into account anthropogenic and biomass burning sources [25]. Higher estimates of $140 \pm 90 \mathrm{Tg} \mathrm{a}^{-1}$ or $240 \pm 140 \mathrm{Tg} \mathrm{a}^{-1}$ [26] also exist, which are based 
on Aerosol Mass Spectrometer and organic carbon observations, modeling, and various assumptions concerning the partitioning of SOA to the aerosol phase and the role of anthropogenic VOCs. A wide range between 87.2 to $501.6 \mathrm{Tg} \mathrm{a}^{-1}$ was also reported [27], which was estimated using different assumptions of SOA volatility and SOA fragmentation, which also impacts volatility. A missing source of the order of 100 $\mathrm{Tg} \mathrm{a}^{-1}$ was also identified as the best way to bridge the gap between aircraft profile organic aerosol measurements and the GEOS-Chem model [28]. A high SOA formation of $150 \mathrm{TgCa}^{-1}( \pm 80 \%)$ was estimated using a top-down approach based on satellite aerosol optical depth (AOD) observations [29], and an even higher source of 140 to $910 \mathrm{TgC}^{-1}$ based on various mass balance approaches [30], although the upper end of that range is probably unrealistic. Regardless of the exact source strength, SOA sources are very high and comparable or higher in magnitude to anthropogenic primary aerosol sources and their impact on climate can be very significant, making SOA a top priority in accurately parameterizing their formation and fate in models. The magnitude of the impact depends on SOA atmospheric load that is determined both by sources and sinks in the atmosphere, their climate relevant properties, and their mixing with other aerosol components $[9,21,18]$.

Although our process-level understanding of SOA formation has seen great advances the last few years thanks to both high quality laboratory studies and field campaigns [21], global models, both CTMs and general circulation models (GCMs), have not followed up with introducing new processes in their calculations [18], with a few exceptions [25, 31-34]. This stems from the number of free parameters that are required to parameterize SOA on the global scale, the computational cost that the new parameterizations come with, primarily due to the large number of tracers that need to be included in the calculations, and person-power required which is not always readily available. Although computationally cheap parameterizations have been developed by using empirical relationships based on measurements [34-36], their applicability in a climate model might be limited. This is due to the large changes occurring over centuries-long simulations or simulations of deep-past climates, where climate and chemical regimes can be greatly different from what we experience now. A comprehensive and fast modern parameterization that integrates most of the new process-level advances for use in global models is yet to be developed.

The objective of this review is to first describe the current state of SOA modeling in CMIP-class models, by zooming in the only model that had interactive SOA calculations during CMIP5, the GISS ModelE2 [37]. Current knowledge about SOA forcing on climate is then presented by describing SOA optical properties. SOA volatility, probably one of the most important OA attributes currently missing from climate models, is explicitly discussed. The current estimates of SOA forcing calculated by several models in the literature, both for the shortwave and longwave, are finally presented. We conclude by proposing a roadmap towards future development needs to more accurately simulate SOA forcing in the next generation climate models.

\section{SOA in climate models during CMIP5}

Coupled climate models, which are atmospheric GCMs coupled with other Earth system compartments like the ocean, the biosphere, the cryosphere and the lithosphere, are highly complex models that require large computational resources to simulate the Earth system even at moderate resolutions. It is not uncommon that coupled climate models ignore processes that are considered 
unimportant for the simulation of the Earth system, or are too expensive computationally and thus are being highly parameterized, or both. The $5^{\text {th }}$ phase of the Coupled Model Intercomparison Project (CMIP5; [38]), whose results were used in the Intergovernmental Panel Climate Change (IPCC) report [39], was designed to create a multi-model dataset for use in climate variability and climate change applications. In such models, any addition of computationally-demanding processes needs to be justified by a noticeable impact on climate, regional or global.

During CMIP5, OA prognostic calculations included only POA: fossil fuel and biomass burning sources directly inject non-volatile OA in the atmosphere. Anthropogenic SOA was explicitly included in just a few models, while biogenic SOA was included using a very simplified approach, which was not the same between models. For example, the HadGEM2-ES [40] used a three-dimensional climatology generated by the STOCHEM CTM [41]; the CSIRO-Mk3.6 GCM [42] assumed a constant fraction (28\%) of terpene emissions [43] to occur as non-volatile SOA; the SPRINTARS aerosol model [44] in MIROC-ESM 2010 [45] used a similar approach but with a yield of just 4\%, while the IPSL-CM5 model [46] used an intermediate yield of 15\% [17], the most common value among models that follow this approach [18]. The GFDL-CM3 model also used the yield approach [47], with yields varying latitudinally and progressively increasing from $11 \%$ at the tropics to $55 \%$ at the poles. This model also included an anthropogenic SOA source, based on $n$-butane oxidation, a surrogate for all hydrocarbons with 4 or more carbons (excluding isoprene and terpenes) that was assumed to produce non-volatile organics with a $10 \%$ yield [48]. The Goddard Institute for Space Studies (GISS) GCM, GISS ModeIE2 [37], was the only model in the CMIP5 archive that included interactive calculations of SOA (calculated by the model at every time step) for transient experiments of both the historical [49] and future projections [50].

In GISS ModelE2, SOA calculations include the aerosol formation from biogenic VOCs oxidation and partitioning of the semi-volatile products, which takes into account the impact of nitrogen oxides $\left(\mathrm{NO}_{x}\right)$ on aerosol formation rates via gas-phase chemistry changes, as implemented in the TM3 [14-16] and ECHAM5-HAM [51] models. Semi-volatile gases are able to condense on and evaporate from preexisting aerosols via their temperature-dependent partitioning coefficients, depending on the atmospheric conditions. The partitioning is the net effect of the SOA formation via condensation and the SOA loss via evaporation at any given time. SOA precursor gases include isoprene, whose emissions are calculated online and depend largely on temperature, leaf area index, and solar radiation ([43]; Fig. 1a). The isoprene emissions time series strongly follows temperature, resulting in an overall increasing trend from 1850 to 2100 . Terpenes annual emissions of $122 \mathrm{Tg} \mathrm{a}^{-1}$ and other reactive VOCs of $71 \mathrm{Tg}^{-1}$ were also considered as SOA precursor sources [4] and were kept constant throughout the simulation, with a spatially-varying annually-repeated seasonal cycle, as calculated by the terrestrial vegetation model ORCHIDEE [52].

Probably counter-intuitively, the formation of SOA from preindustrial into the future via partitioning of the gas-phase oxidation products of its VOC precursors (Fig. 1b) closely followed the time evolution of POA concentrations (Fig. 1c), which were driven by the decadal-mean POA emissions provided by CMIP5 [53], rather than SOA precursor sources. This demonstrates the importance of preexisting aerosols on SOA formation in a changing climate, at least using the GISS ModelE2 and the processes that takes into account, under the assumption that all SOA are able to evaporate under 
favorable conditions, which is not always the case in the real atmosphere [54-56]. The time series of the total SOA burden calculated by the model (Fig. 1d) generally resembles that of SOA formation, as expected.

\section{Current state of knowledge on SOA direct radiative forcing}

Several factors are involved in accurately simulating the direct SOA impact on climate and the climate feedback to SOA. Other than climate parameters affecting forcing like the radiation distribution in the atmosphere and the presence of clouds, SOA forcing is proportional to SOA AOD, which can be calculated as the product of the SOA column abundance and SOA mass extinction efficiency, a measure of aerosol light extinction per unit mass [57]. Care must be taken in the exact definition of extinction efficiency, which can be found as extinction coefficient in the literature, with the "extinction efficiency" term being used differently [58]. The extinction efficiency, which is the sum of the scattering and absorption efficiencies, depends on the chemical composition of SOA and changes with wavelength, based on the wavelength-dependence of its refractive index, which describes how light propagates through a medium.

For the column abundance calculation, aerosol sources, transport, processing and removal have to be taken into account. Then, the different optical properties of the various SOA species are used to calculate the AOD of the different SOA species for a given size distribution. Aerosol microphysical properties, including their size distribution and mixing state, also impact the effective optical properties of both pure and mixed aerosol populations. OA coating that forms via condensation can amplify freshly emitted fractal Black Carbon (BC) absorption by up to $15 \%$ and scattering by up to $100 \%$, depending on the refractive index of the coating material [59]. When neglecting the enhanced absorption of $B C$ that is internally mixed with OA, the mass absorption efficiency of OA can be biased high by up to 50\% [60]. SOA are also known to be important in new particle formation [34], which influences aerosol number concentration and can affect both the direct [13] and indirect [61-64] radiative forcing.

Although remarkably complex, for climate modeling purposes the SOA representation needs to be reduced to the minimum amount of species, processes and properties required to accurately simulate the radiative effects of SOA on climate, rather than focus on simulating atmospheric composition in all the great detail measured in the field. For this, all discussion below will focus on the radiative forcing potential of SOA, and only go into the finer process-based details that might matter as a direct climate forcing agent.

\subsection{SOA optical properties}

Due to the enormous complexity of SOA in the atmosphere, which is a result of different sources, processing, removal, and the spatiotemporal heterogeneity of them, SOA optical properties are expected to change with aerosol composition. Indeed, this was demonstrated in chamber experiments for both SOA [65] and total OA [66]. However, only few systematic studies exist that try to resolve the change of optical properties of OA as a function of composition $[67,68]$.

There can be two types of SOA in models, based on SOA optical properties determined experimentally: the non-absorbing and the absorbing ones, while both scatter radiation. The former is 
frequently called "white" in the literature and the latter is called brown carbon $(\mathrm{BrC})$, due to its brown color at visible wavelengths. Most models use similar refractive indices for non-BrC OA (both POA and SOA) at $550 \mathrm{~nm}$ : 1.53-0.006i (Table 1), a value that probably originated from the OPAC database [69] or even earlier. The choice of this value makes non-BrC SOA slightly absorbing in models, since the imaginary part of the refractive index is non-zero. There exist at least two notable exceptions: GISS ModelE, which has a higher imaginary part $(0.014$; [37]) that implicitly assumes that $O A$ is a little more absorbing than other models and thus implying the presence of $\mathrm{BrC}$ without explicitly modeling it, and HADGEM2-ES, which assumes that SOA is completely scattering and has a lower real part than all other models. GEOSChem-APM also uses a low real part for SOA (1.45; [70]) that was derived from model calculations evaluated against data across Europe [71]. The models listed in Table 1 are among the ones that participate in AeroCom [72], which are occasionally either CMIP-class models (e.g. GISS ModelE, HADGEM2-ES), or aerosol modules of CMIP-class models (e.g. GOCART, SPRINTARS). Not all models are surveyed in Table 1, and similar or additional differences might exist in unlisted models.

Overall, the refractive index of aerosol components, and especially its wavelength dependence, is one of the most poorly documented parameters in aerosol global modeling.

\subsubsection{Non-absorbing SOA}

While there is tremendous momentum in the determination of the refractive index of $\mathrm{BrC}$ (see next section), there are few recent studies that aim to measure the refractive index of non- $\mathrm{BrCOA}$ in the laboratory or in the field (summarized in [73]). Most of these studies measure the real part of the refractive index without concurrent determination of the imaginary part.

The real part used by models approximates aged SOA as measured in chamber experiments [65] and not fresh SOA which has been measured to have a real part of its refractive index as low as 1.38 [65]. Aging was found to further modify the chemical composition of OA and its optical properties in chamber experiments [66, 74], with photochemical oxidation and dark oxidation having different effects. SOA with different volatilities has been also shown to have different real refractive indices [75]. During the Deep Convective Clouds and Chemistry (DC3) field experiment the real part of the refractive index of mixed aerosols (more than $50 \%$ organics by mass) was found to be around 1.5 and slightly decreasing with increasing altitude [76], although no global conclusions can be deduced from a few profiles during a single campaign. In addition, studies have shown that the real part of the SOA refractive index decreases with increasing wavelength in the visible $[77,78]$, but no studies exist for its refractive index in the infrared (IR).

The different refractive indices per SOA compound would impact radiative forcing calculations, had these finding been introduced in model calculations. Whether the refractive index of purely scattering SOA changes with time, composition and wavelength, and especially with regard to its IR absorption, is negligible for climate purposes, is yet to be quantified. To our knowledge, there is no study trying to quantify the model sensitivity of the SOA refractive index choice on neither shortwave nor longwave radiative forcing.

\subsubsection{Absorbing SOA}


$\mathrm{BrC}$, a subset of organic aerosols, is a complex mixture of organic compounds lacking a formal analytical definition. Its light absorption is weaker than that of $\mathrm{BC}$, with mass absorption efficiency less than $1 \mathrm{~m}^{2} \mathrm{~g}^{-1}$ at $550 \mathrm{~nm}$, but a strong wavelength dependence [79]. $\mathrm{BrC}$ absorption increases rapidly into the UV spectral region [80], which is the typical way to experimentally separate organic absorption from that of $B C$ [81], which shows no wavelength dependence in the visible [82]. Organic material can lead to enhanced absorption [83] either by absorbing light itself (which is source-dependent and not well quantified) or by absorption amplification [84], where coating of non-absorbing material around BC or other absorbing particles increase the overall absorption of the mixed particle [83]. Depending on what measurement technique is used, measurements may quantify one or the other or both.

$\mathrm{BrC}$ can be directly emitted in the atmosphere [85], or form chemically by non-absorbing aerosol precursors and precursor gases. Among the processes currently missing from most climate models, one of the most important is the aqueous chemistry of soluble gaseous organic compounds, both in cloud [86] and aerosol water [87-90], which leads to the formation of SOA [91, 92, 31]. Its importance lies not only in the fact that it can form new organic aerosol mass; products from aqueous chemistry, and primarily from aerosol water chemistry, can be light absorbing BrC [93]. The formation of SOA in the aqueous phase (aqSOA) is important for SOA, and models and measurements occasionally disagree on the importance of cloud water as a medium for aqSOA formation compared to that of aerosol water [94, 95]. A possible reason for this disagreement is that oxalate, whose typical concentration is less than $5 \%$ of total OA in cloud water, has been used as the proxy for measuring cloud aqSOA, because it is hard to separate total SOA from aqSOA in measurements [92]. Uncertainties in oxalate formation pathways in clouds can strongly influence our understanding when modeling oxalate and extrapolating that to total aqSOA.

Although part of $\mathrm{BrC}$ is primary in nature, it can rapidly change optical properties by either bleaching [96-99] or browning [100]. For this, it will be considered here as light absorbing SOA, since it is its time-evolving optical properties that affect climate in the long term, rather than those at emission time. The $\mathrm{BrC}$ formation rate has been measured in laboratory experiments [101], as has the complex refractive index of toluene-SOA as a function of $\mathrm{NO}_{x}$ levels [78]. Reactions of both anthropogenic and biogenic SOA precursors with gaseous $\mathrm{NH}_{3}$ have also been found to form $\mathrm{BrC}$ [102]. There is evidence from laboratory studies that particle-phase chemical reactions of organics with inorganic salts can produce SOA which absorbs light in the UV and visible [80], and this absorption can be pH-dependent [103]. The refractive index of $\mathrm{BrC}$ has been also measured in the field [104]. In the real atmosphere, where aerosols are much more complex, $\mathrm{BrC}$ identification remains a challenge. Organic absorption attributed to $\mathrm{BrC}$ has been measured in a number of locations around the globe [105-108] and has been found to be associated with the water soluble fraction of $\mathrm{OA}$ [109]. $\mathrm{BrC}$ has been observed in air influenced by either pollution or the burning of biomass or biofuel [110], with nitro-aromatic compounds contributing at least half of the biomass burning absorption across a wide range of visible wavelengths [111]. The presence of $\mathrm{BrC}$ in $\mathrm{OA} / \mathrm{BC}$ mixtures modifies absorption and absorption amplification, with $\mathrm{BrC}$ absorption increasing during biomass burning while the ratio of $\mathrm{BC}: \mathrm{OA}$ increases [112]. Solid or semi-solid organic aerosols (tar balls) also absorb solar light and in that context can be also considered as $\operatorname{BrC}$ [113].

One of the biggest uncertainties when it comes to $\mathrm{BrC}$ is its spectrally-varying refractive index, which can be used for its detection $[114,102]$. Studies exist [115] that used a refractive index of 1.67-0.27i 
without spectral dependence, by assuming that the less than $10 \%$ measured changes in the real and imaginary parts of the refractive index [104] are not significant in terms of radiative forcing calculations. A constant real part of the $\mathrm{BrC}$ refractive index was mostly used in past studies, with very similar values being used, equal to 1.53 [116], 1.55 [117, 110], and 1.67 [115], all within the reported range of spectrallyvarying values [104]. However, the radiative forcing efficiency of $\mathrm{BrC}$ (radiative forcing per unit mass) can differ by a factor of 3 and even change sign between near-UV and mid-visible wavelengths, an effect that was attributed to changes in the imaginary refractive index of $\mathrm{BrC}$ alone [117]. The dependence of the imaginary part of the refractive index on wavelength differs widely between studies: it can be as strong as orders of magnitude change between 350nm and 700nm [117] based on refractive indices estimated by different studies $[79,116]$, while other studies [104] calculated a much more modest change, even for a wider wavelength range. The chemical nature of $\mathrm{BrC}$ can be responsible for these differences: low temperature combustion processes, including biomass burning, produce light-absorbing aerosols that exhibit much stronger spectral dependence than do high-temperature combustion processes, such as diesel combustion [79]. An enhanced absorption by OA in the summer months in southern California (related to forest fires and SOA) has also been attributed to $\mathrm{BrC}$ [118], where its absorption at $440 \mathrm{~nm}$ was measured to be $40 \%$ of that of elemental carbon, whereas at $675 \mathrm{~nm}$ it was less than $10 \%$ of that of elemental carbon.

Theoretical calculations have shown that if $\mathrm{BC}$ is coated by $\mathrm{BrC}$, instead by a purely scattering shell, the absorption amplification diminishes [83]. Field measurements confirmed this calculation, although the $\mathrm{BrC}$ shell absorption ultimately leads to increased absorption of the mixed particle that can also contain purely scattering agents like sulfate and "white" OA [119]. BrC significantly contributes to light absorption in the early morning [120], a fact also supported by laboratory experiments [87].

\subsection{SOA volatility}

The volatility of SOA has been shown to be of importance in all contexts, both experimental and theoretical. Its determination in the field can be subject to artefacts and can vary significantly between experimental approaches [56], with important implications in simulating aerosol volatility in models. The temperature dependence of volatility, which is characterized by the enthalpy of vaporization $\left(\Delta H_{v a p}\right)$, is of great importance for SOA formation [14]. Semi-empirical parameterizations have been proposed to calculate $\Delta H_{\text {vap }}$ as a function of SOA volatility [121]. Measurements of $\Delta H_{\text {vap }}$ differ by a factor of 3 for different SOA compounds [122-124], a variability that greatly impacts model results [14] that can't simply be worked around by the use of a surrogate compound group $[125,126]$.

Compounds with different volatilities have different physical, chemical and optical properties, and it is of importance to simulate them accurately, since the vertical distribution of aerosols changes aerosol radiative forcing potential, especially for absorbing compounds [127], and aerosol lifetime [55]. Changes in the volatility of bulk SOA occur either via aging in the atmosphere to higher functionality compounds or oligomerization (which leads to decreased volatility) or fragmentation (which leads to increased volatility), or via changes in the atmospheric conditions (e.g. temperature). It is now almost 20 years since models first simulated the presence of SOA in the upper troposphere $[9,14,128]$, a finding that was supported by aircraft measurements [28]. Only very recently solid measurements were made available that explain the presence of SOA in the upper troposphere [129], which is due to convective transport of 
organic gases and their precursors that are too volatile to condense near the surface, but partition in the aerosol phase at sufficiently low temperatures. The conversion of semi-volatile SOA to non-volatile is the dominant factor generating variability in surface-level SOA during daytime in models [130]. Larger model diversity has been found in the upper free troposphere than at surface, in particular over the poles, leading to the similar conclusion that the processes involving low temperatures are not well constrained or they are absent in models $[18,130]$.

\subsection{SOA radiative forcing}

In GISS ModelE2 (Fig. 1), the AOD of SOA changes linearly with its burden from a global mean value of 0.007 in the preindustrial to about 0.0095 at present day, until decreasing again to almost the preindustrial levels in 2100, and is of comparable magnitude with that of POA (not shown). Both the SOA chemical production and burden of GISS ModelE2 lie at the low end of the range of the global models that participated in the AeroCom OA intercomparison [18]. Such OA underestimation was however demonstrated that was the typical behavior for most models when comparing models against measurements.

The calculated SOA direct forcing maximizes in the decades around the year 2000 for both the shortwave (Fig. 1e) and longwave (Fig. 1f), consistent with the change in SOA burden with time. Regardless of which representative concentration pathway ( $R C P$ ) projection is used as a future scenario, the calculated SOA forcing does not differ significantly from each other when compared to SOA forcing interannual variability (less than 10\%), which is smaller than the 250 year calculated changes (about 30 $35 \%)$. Compared with other aerosol components, the SOA shortwave forcing is calculated to be roughly the same with that of POA, 4 times smaller than that of sulfate aerosols and 3 times smaller than that of BC (but opposite in sign) in GISS ModelE2, while the SOA longwave forcing is about $50 \%$ higher than that of sulfate and almost an order of magnitude higher than that of POA and BC. This strongly depends on the choice of OA optical properties, as detailed above. In GISS ModeIE2, SOA and POA have the same optical properties; their large difference in longwave forcing is therefore probably related to the vertical distribution of aerosols: POA stays mostly in the lower part of the troposphere, while SOA can extend all the way to the tropopause $[9,18,14]$.

In global climate models, due to the high uncertainties in SOA calculations and to save computational resources, SOA was treated as part of POA. A key implicit assumption in justifying this was that the OA forcing on climate would add linearly between POA and SOA, assuming negligible nonlinearities between the two OA components. Although on first order this assumption is reasonable, when feedbacks are introduced it might not stand. Such a complication was demonstrated when comparing single-forcing experiments in CMIP5 with the sum of the response: when chemistry and aerosols were not calculated interactively (prognostically), single forcings were adding fairly linearly, while when interactive chemistry and aerosols were introduced in the calculations feedbacks via precipitation changes were far too large to be considered negligible [131]. The feedbacks introduced with interactive atmospheric composition calculations had consequences for important climate variables even the largest scales, making the addition of single forcing experiments statistically different at $99 \%$ level of confidence from the simulations where all forcings were applied simultaneously. The results presented in Fig. 1 together with the large difference in longwave forcing between POA and SOA demonstrate that the case of SOA 
might be one additional example of non-linear feedbacks that need to be taken into account in futuregeneration models. Feedbacks in the Earth system are very important for SOA, since changes in temperature affect reaction rates, partitioning, and vegetation distribution, changes in $\mathrm{CO}_{2}$ affect vegetation photosynthetic rates, and changes in aerosols affect the ratio of diffuse/direct solar radiation, which also affect photochemistry, photosynthesis and biogenic SOA precursor emissions [132, 133]. In addition, changes in meteorology modify precipitation, a major removal mechanism for all aerosols. Precipitation also changes in a changing climate, adding an additional feedback mechanism to SOA budget.

Most studies to-date either calculate the shortwave forcing of SOA, or do not explicitly state whether they report the shortwave or total forcing. Since the longwave forcing of SOA is smaller in magnitude than the shortwave one (because most of SOA resides in small aerosol sizes) and negligible compared to cloud longwave forcing, when no clear statement is made about shortwave or total forcing in the literature, we present here those results as shortwave forcing. In addition, care must be taken when studies compare anthropogenic forcing, which is the difference between a present-day and a preindustrial simulation, since the levels of natural aerosols during preindustrial are strongly impacting the overall anthropogenic aerosol forcing, especially when that involves aerosol-cloud interactions [134].

\subsubsection{Shortwave}

The shortwave SOA forcing has both a scattering and an absorption component, depending on the chemical composition and mixing state of SOA, based on the effective refractive index of the mixed aerosol population. In addition, the absorption of UV radiation by $\mathrm{BrC}$ has the potential to perturb tropospheric photochemistry, reducing ozone levels at the lower layers of the atmosphere $[135,136]$. BrC can also affect the upper parts of the troposphere [137], where UV radiation is more abundant. BC was found to increase its radiative forcing efficiency with altitude [127], mostly because when BC is above clouds the underlying surface albedo increases $[138,139]$. This is probably true for $\mathrm{BrC}$ as well, since two thirds of the total BrC forcing occurs in the upper half of the troposphere, despite its small amount at those altitudes, making it an unappreciated component of climate forcing [137].

There are several estimates of the SOA forcing in the literature, but not all of them are directly comparable to each other, due to the different assumptions in models. Two key parameters need to be considered when comparing forcing numbers from the literature among models: one, whether $\mathrm{BrC}$ has been considered in any of the models, and two, whether that $\mathrm{BrC}$ is assumed to be primary (i.e. directly emitted), secondary (i.e. chemically produced), or both. In addition, care must be taken regarding the aging of OA: for example, there are models that consider aged POA as SOA [140], which is a common assumption when using the volatility-basis set (VBS) to represent OA [141]. As of today, there are no CMIPclass models using VBS, but this framework is now being adopted by an increasing number of models, both regional and global, so the direct comparison of POA and SOA between studies might become more challenging in the future.

The overall range of SOA direct forcing reported in the literature spans from $-0.01 \mathrm{~W} \mathrm{~m}^{-2}$ to -0.78

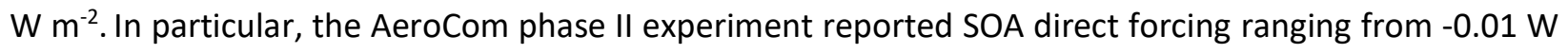
$\mathrm{m}^{-2}$ to $-0.21 \mathrm{~W} \mathrm{~m}^{-2}$ [142], with a mean (median) value of $-0.06(-0.02) \mathrm{W} \mathrm{m}^{-2}$, a value that is greatly affected by the SOA burden in each model. Indeed, in the GLOMAP model the direct forcing is calculated to range 
between -0.08 and $-0.18 \mathrm{~W} \mathrm{~m}^{-2}$ depending on physics assumptions, but it becomes $-0.09,-0.33$, and -0.78 $\mathrm{W} \mathrm{m}^{-2}$ for half, 2-times, and 5-times the SOA mass yield, respectively [63], an almost linear relationship between source strength and forcing. A range of SOA forcing as high as -0.26 to $-0.5 \mathrm{~W} \mathrm{~m}^{-2}$ has been calculated with different volatility and fragmentation assumptions [27], although this range corresponds to much higher SOA burden than in most models. The anthropogenically controlled SOA, which comes from a SOA source linked to CO emissions [26], was found to create a direct forcing of $-0.26 \pm 0.15 \mathrm{~W} \mathrm{~m}^{-2}$, with the uncertainty coming from a range of possible anthropogenic emission fluxes. Care should be taken though when classifying anthropogenic vs. biogenic SOA, since anthropogenic emissions can affect biogenic SOA formation by changing atmospheric composition and impacting the chemical formation of biogenic SOA [12, 26, 143]. In addition, as was demonstrated in Fig. 1, the impact of the largely anthropogenic POA on biogenic SOA partitioning can also complicate the attribution of a given SOA mass as anthropogenic or biogenic, since the chemical identity of SOA would be secondary but the physical process that favored partitioning of biogenic semi-volatile gases in the aerosol phase can be anthropogenic in nature. The size and refractive index of aerosols also contribute to the SOA forcing uncertainty, which was calculated to range from -0.12 to $-0.31 \mathrm{~W} \mathrm{~m}^{-2}$ in the IMPACT model [116], a range which also includes sensitivity studies between strongly and weakly absorbing BrC. Over China the choice of refractive index for SOA affected forcing results by more than $50 \%$ [73]. BrC reduces the cooling effect of OA by $16 \%$, which highlights its significance on the total OA forcing [144].

The choice of the nominal reference year is also affecting anthropogenic forcing calculations. The GEOS-Chem-TOMAS model calculated that biogenic VOC emissions changes during the last millennium exert a positive total aerosol forcing between +0.022 and $+0.163 \mathrm{~W} \mathrm{~m}^{-2}$, which is a combination of SOA source strength and size distribution changes, an effect which is probably overlooked [64]. This impact is larger regionally, since over oceans the forcing is less than $+0.05 \mathrm{~W} \mathrm{~m}^{-2}$, but over land there are large regions that can exceed $+0.5 \mathrm{~W} \mathrm{~m}^{-2}$ [64].

The evolution of SOA burden into the future has been studied mostly using the year 2100 as a reference. In the CAM3 model, a 36\% increase in SOA burden was calculated and attributed to both increases in SOA precursors and POA emissions [145]. An increase equal to $54 \%$ in SOA burden was calculated by the GISS II' model from present day to 2100 , while POA was more than doubled during the same period. The change of OA resulted in a total OA forcing of $-0.58 \mathrm{~W} \mathrm{~m}^{-2}$ [146]. Using future climate (as forced by $\mathrm{CO}_{2}$ concentrations and natural emissions) but present-day anthropogenic emissions, SOA increased by $8 \%$ due to climate change impacts on natural emissions and chemistry [146]. In both simulations, a 50\% increase of SOA precursor emissions was used but resulted in different increases in SOA burden: $8 \%$ without and $54 \%$ with changes in anthropogenic emissions, that shows a non-linear response of SOA formation to precursor emission changes. POA, the main SOA burden driver at centennial timescales based on GISS ModelE2 results, remained constant in the GISS II' simulation with the modest SOA increase, which makes it likely that POA is also a key driver in GISS II'. A similar result was obtained with the TM3 model, where an increase by a factor of 2.5 in SOA burden was calculated, as a result of a doubling of POA emissions, $50 \%$ increase of isoprene emissions, and doubling of monoterpenes emissions [16]. Keeping SOA precursor emissions to present-day levels contributed to an increase on the SOA burden by $16 \%$, a result of increased POA. The SOA forcing due to the SOA burden increase between present-day and the year 2100 ranges between -0.04 and $-0.24 \mathrm{~W} \mathrm{~m}^{-2}$ [133]. These results should be compared with 
those presented in Fig. 1 from GISS ModelE2, where a decrease of POA, an increase of isoprene, and constant terpenes emissions led to a decrease of SOA in the future, resulting in a decrease in forcing to about -0.11 to $-0.12 \mathrm{~W} \mathrm{~m}^{-2}$ for the various emission scenarios in the shortwave in 2100 , a bit higher than the 1850 forcing.

\subsubsection{Longwave}

Very few studies have focused on the longwave forcing of aerosols other than sulfate and dust, although these calculations are implicitly present in all GCMs. Alaskan boreal fires have been shown to affect more the longwave rather than the shortwave [147], with most of the response coming from surface temperature changes rather than biomass burning emissions, including OA. In the Himalayan region the longwave forcing of total aerosols was found to exceed that of the shortwave [148], which was suggested to be an important contributor to the climate of the region. Longwave forcing was also found to correlate well with temperature changes and had a different distribution during monsoon and nonmonsoon seasons.

On the global scale, SOA direct longwave forcing since preindustrial times was calculated with the ECHAM-HAM model to be $+0.02 \mathrm{~W} \mathrm{~m}^{-2}$ under clear-sky conditions [51], which is comparable in magnitude with the $+0.01 \mathrm{~W} \mathrm{~m}^{-2}$ presented in Fig. If from the GISS ModelE2 for all-sky. Both models use the same SOA parameterizations, but ECHAM-HAM includes aerosol microphysics, while GISS ModelE2 uses a bulk aerosol scheme. The small value of this number is due to the size of SOA which is in general much smaller than the wavelength of light in the longwave, and has been considered to be negligible when compared to total longwave changes due to clouds [149] in the CAM3 model. Although this assumption is reasonable, since only desert dust aerosols (due to their high burden) and volcanic sulfate aerosols in the stratosphere (due to their high altitude) contribute significantly to the total aerosol longwave forcing [150], it needs to be quantified with other models as well. The almost an order of magnitude difference in longwave forcing in the GISS ModelE2 between POA and SOA serves as an indicator that SOA longwave forcing, probably due to their presence in the upper troposphere, is an underappreciated climate forcer.

\section{Climate modeling of SOA in future-generation models}

Climate modeling will remain a challenging field, where the choice between accurate but computationally-demanding parameterizations and model performance need to be balanced. Given the fact that climate models are primarily used to understand present climate, reproduce past climates, and predict future climate change, any new parameterizations need to be developed in a way that serve this primary goal, climate prediction. A climate model is not the tool to accurately simulate atmospheric composition with the maximum detail possible, which means that reducing, or even eliminating processes that are important for atmospheric composition but not for climate is a common compromise. For SOA direct effect, this reduces to simulating SOA concentration and optical properties in space and time, which then allows the estimation of the radiative impact of SOA on the global scale, rather than calculating the detailed SOA formation and composition. In CMIP5 all models had major weaknesses in accurately simulating SOA distribution, thus all results presented above are subject to change after implementing missing sources and processes. The direction of change is hard to predict, though, but it is likely that for CMIP6 there will be many more models having more detailed SOA calculations, and not just one. 
Although it is not yet clear which of the SOA formation pathways recently discovered [21] are key in simulating the atmospheric SOA distribution, volatility is probably sitting at the top of the priority list for OA model development. This likely includes both the inclusion of emissions of compounds with different volatilities, either using the VBS approach or not, but also the chemical processing that alters the volatility distribution in the atmosphere, both increasing it (e.g. fragmentation) and decreasing it (e.g. functionalization, oligomerization). Although we do have some information already, in order to accurately simulate volatility of $\mathrm{OA}$ and its atmospheric evolution with time and space (including temperature changes) more systematic laboratory and field studies are needed to explore the parameter space of the global atmosphere, including high altitudes. In addition, emission inventories need to be altered to both split the current OA emissions in volatility classes, and also include more information of the IVOCs that are currently missing. It is known for more than a decade that different assumptions in SOA volatility calculations can affect its vertical distribution, including irreversible sticking of semi-volatile organics [14]. Since a significant fraction of SOA is semi-volatile [21 and references therein], and parameterizations of different complexities already exist in the literature, they need to be included in all GCMs. The temperature dependence of volatility is also known to be of paramount importance for aerosol distribution [14], but this factor is less constrained and is frequently handled as a free parameter by models. The results of GISS ModeIE2 regarding the effect of POA on SOA likely mean that either POA is too high, or SOA too volatile, or both. Comparisons with field measurements of OA volatility should be able to guide future model development and constrain this uncertainty.

The most important sources of SOA precursors are already included in models, but important processing of them is still missing from climate models. This includes processes like aqueous formation and modification, oligomerization, fractionation, and formation of newly identified products, to name a few. The processes that affect volatility (e.g. oligomerization) and optical properties (e.g. aqueous processing) are important to be included first. The model particularities, complexity and the different priorities research groups have on using their models to answer non-climate questions, will likely guide future developments. A number of chemistry/transport models already include aqueous chemistry of OA in their parameterizations with different degrees of complexity [31, 151], which are not very computationally demanding for use in a climate model. Indeed, the GFDL AM3 model already contains aqueous OA formation in its calculations $[152,153]$.

In terms of optical properties, the formation of $\mathrm{BrC}$ (direct emissions and chemistry) and its processing via bleaching and browning is critical for the accurate simulation of SOA scattering, absorption, and forcing. Given the large diversity of what really $\mathrm{BrC}$ is, it appears likely that for climate purposes simulating the evolution of the refractive index of $O A$ is an achievable target, rather than simulating numerous individual chromophores and their atmospheric fate. The wavelength dependence of the refractive indices of both $\mathrm{BrC}$ and "white" SOA should also be investigated experimentally, from the nearUV to the IR. The timescale of bleaching is expected to be a very important and uncertain parameter in these calculations, given the range of half-lives estimated in the field and in laboratory experiments that span from a few minutes to more than half a day $[99,154]$.

Two additional important parameters affect SOA burden and optical properties: its hygroscopicity and its microphysics (size distribution and mixing state). Since it is well established that SOA is generally 
hydrophilic, and is becoming even more with aging, a simple parameterization might suffice for climate models. The size distribution of SOA affects optical properties, but if a wavelength dependent refractive index is known (either for white or brown SOA) simple calculations based on each model's assumptions on aerosol microphysics can be used to parameterize this effect for climate applications.

Finally, it is stated that almost all OA in the atmosphere is chemically processed, which moves us to a new view of $O A$ in the atmosphere and its modeling: from primary inert POA in the past, to chemically processed and reactive SOA, including $\mathrm{BrC}$, now and in the future. The years to come are expected to unveil the next generation of $\mathrm{OA}$ models with exciting new capabilities that will likely help us promote our understanding of the Earth system as a whole and understand its evolution in time. 


\section{References}

1. Odum JR, Hoffmann T, Bowman F, Collins D, Flagan RC, Seinfeld JH. Gas/Particle Partitioning and Secondary Organic Aerosol Yields. Environmental Science \& Technology. 1996;30(8):2580-5. doi:10.1021/es950943+.

2. Odum JR, Jungkamp TPW, Griffin RJ, Flagan RC, Seinfeld JH. The atmospheric aerosol-forming potential of whole gasoline vapor. Science. 1997;276(5309):96-9. doi:10.1126/science.276.5309.96.

3. Hoffmann T, Odum JR, Bowman F, Collins D, Klockow D, Flagan RC et al. Formation of Organic Aerosols from the Oxidation of Biogenic Hydrocarbons. Journal of Atmospheric Chemistry. 1997;26(2):189-222. doi:10.1023/A:1005734301837.

4. Griffin RJ, Cocker DR, Seinfeld JH, Dabdub D. Estimate of global atmospheric organic aerosol from oxidation of biogenic hydrocarbons. Geophysical Research Letters. 1999;26(17):2721-4. doi:10.1029/1999gl900476.

5. Pandis SN, Paulson SE, Seinfeld JH, Flagan RC. Aerosol formation in the photooxidation of isoprene and $\beta$-pinene. Atmospheric Environment Part A General Topics. 1991;25(5):997-1008. doi:10.1016/09601686(91)90141-S.

6. Kroll JH, Ng NL, Murphy SM, Flagan RC, Seinfeld JH. Secondary organic aerosol formation from isoprene photooxidation under high-NOx conditions. Geophysical Research Letters. 2005;32(18). doi:10.1029/2005gl023637.

7. Kroll JH, Ng NL, Murphy SM, Flagan RC, Seinfeld JH. Secondary organic aerosol formation from isoprene photooxidation. Environmental Science \& Technology. 2006;40(6):1869-77. doi:10.1021/es0524301.

8. Guenther AB, Jiang X, Heald CL, Sakulyanontvittaya T, Duhl T, Emmons LK et al. The Model of Emissions of Gases and Aerosols from Nature version 2.1 (MEGAN2.1): an extended and updated framework for modeling biogenic emissions. Geosci Model Dev. 2012;5(6):1471-92. doi:10.5194/gmd-5-1471-2012.

9. Kanakidou M, Seinfeld JH, Pandis SN, Barnes I, Dentener FJ, Facchini MC et al. Organic aerosol and global climate modelling: a review. Atmos Chem Phys. 2005;5:1053-123.

10. Pankow JF. An absorption model of gas/particle partitioning of organic compounds in the atmosphere. Atmos Environ. 1994;28(2):185-8. doi:10.1016/1352-2310(94)90093-0.

11. Pankow JF. An absorption model of the gas/aerosol partitioning involved in the formation of secondary organic aerosol. Atmos Environ. 1994;28(2):189-93. doi:10.1016/1352-2310(94)90094-9.

12. Kanakidou M, Tsigaridis K, Dentener FJ, Crutzen PJ. Human-activity-enhanced formation of organic aerosols by biogenic hydrocarbon oxidation. J Geophys Res-Atmos. 2000;105(D7):9243-54.

13. Chung SH, Seinfeld JH. Global distribution and climate forcing of carbonaceous aerosols. Journal of Geophysical Research: Atmospheres. 2002;107(D19):4407. doi:10.1029/2001JD001397.

14. Tsigaridis K, Kanakidou M. Global modelling of secondary organic aerosol in the troposphere: a sensitivity analysis. Atmos Chem Phys. 2003;3:1849-69.

15. Tsigaridis K, Krol M, Dentener FJ, Balkanski Y, Lathiere J, Metzger S et al. Change in global aerosol composition since preindustrial times. Atmos Chem Phys. 2006;6:5143-62.

16. Tsigaridis K, Kanakidou M. Secondary organic aerosol importance in the future atmosphere. Atmos Environ. 2007;41(22):4682-92. doi:10.1016/j.atmosenv.2007.03.045. 
17. Dentener F, Kinne S, Bond T, Boucher O, Cofala J, Generoso S et al. Emissions of primary aerosol and precursor gases in the years 2000 and 1750 prescribed data-sets for AeroCom. Atmos Chem Phys. 2006;6(12):4321-44. doi:10.5194/acp-6-4321-2006.

18. Tsigaridis K, Daskalakis N, Kanakidou M, Adams PJ, Artaxo P, Bahadur R et al. The AeroCom evaluation and intercomparison of organic aerosol in global models. Atmos Chem Phys. 2014;14(19):10845-95. doi:10.5194/acp-14-10845-2014.

19. Zhang $Q$, Jimenez JL, Canagaratna MR, Allan JD, Coe H, Ulbrich I et al. Ubiquity and dominance of oxygenated species in organic aerosols in anthropogenically-influenced Northern Hemisphere midlatitudes. Geophysical Research Letters. 2007;34(13):6. doi:L13801, 10.1029/2007gl029979.

20. Jimenez JL, Canagaratna MR, Donahue NM, Prevot ASH, Zhang Q, Kroll JH et al. Evolution of Organic Aerosols in the Atmosphere. Science. 2009;326(5959):1525-9. doi:10.1126/science.1180353.

21. Shrivastava M, Cappa CD, Fan J, Goldstein AH, Guenther AB, Jimenez JL et al. Recent advances in understanding secondary organic aerosol: Implications for global climate forcing. Reviews of Geophysics. 2017;55(2):509-59. doi:10.1002/2016RG000540.

22. Volkamer R, Jimenez JL, San Martini F, Dzepina K, Zhang Q, Salcedo D et al. Secondary organic aerosol formation from anthropogenic air pollution: Rapid and higher than expected. Geophysical Research Letters. 2006;33(17). doi:10.1029/2006gl026899.

23. Hodzic A, Jimenez JL, Madronich S, Canagaratna MR, DeCarlo PF, Kleinman L et al. Modeling organic aerosols in a megacity: potential contribution of semi-volatile and intermediate volatility primary organic compounds to secondary organic aerosol formation. Atmos Chem Phys. 2010;10(12):5491-514. doi:10.5194/acp-10-5491-2010.

24. Hallquist $M$, Wenger JC, Baltensperger $U$, Rudich $Y$, Simpson $D$, Claeys $M$ et al. The formation, properties and impact of secondary organic aerosol: current and emerging issues. Atmos Chem Phys. 2009;9(14):5155-236.

25. Hodzic A, Kasibhatla PS, Jo DS, Cappa CD, Jimenez JL, Madronich S et al. Rethinking the global secondary organic aerosol (SOA) budget: stronger production, faster removal, shorter lifetime. Atmos Chem Phys. 2016;16(12):7917-41. doi:10.5194/acp-16-7917-2016.

26. Spracklen DV, Jimenez JL, Carslaw KS, Worsnop DR, Evans MJ, Mann GW et al. Aerosol mass spectrometer constraint on the global secondary organic aerosol budget. Atmos Chem Phys. 2011;11(23):12109-36. doi:10.5194/acp-11-12109-2011.

27. Shrivastava M, Easter RC, Liu X, Zelenyuk A, Singh B, Zhang K et al. Global transformation and fate of SOA: Implications of low-volatility SOA and gas-phase fragmentation reactions. Journal of Geophysical Research: Atmospheres. 2015;120(9):4169-95. doi:10.1002/2014JD022563.

28. Heald CL, Coe H, Jimenez JL, Weber RJ, Bahreini R, Middlebrook AM et al. Exploring the vertical profile of atmospheric organic aerosol: comparing 17 aircraft field campaigns with a global model. Atmos Chem Phys. 2011;11(24):12673-96. doi:10.5194/acp-11-12673-2011.

29. Heald CL, Ridley DA, Kreidenweis SM, Drury EE. Satellite observations cap the atmospheric organic aerosol budget. Geophysical Research Letters. 2010;37. doi:10.1029/2010gl045095.

30. Goldstein AH, Galbally IE. Known and unexplored organic constituents in the earth's atmosphere. Environmental Science \& Technology. 2007;41(5):1514-21. doi:10.1021/es072476p. 
31. Myriokefalitakis S, Tsigaridis K, Mihalopoulos N, Sciare J, Nenes A, Kawamura K et al. In-cloud oxalate formation in the global troposphere: a 3-D modeling study. Atmos Chem Phys. 2011;11(12):5761-82. doi:10.5194/acp-11-5761-2011.

32. Marais EA, Jacob DJ, Jimenez JL, Campuzano-Jost P, Day DA, Hu W et al. Aqueous-phase mechanism for secondary organic aerosol formation from isoprene: application to the southeast United States and co-benefit of SO2 emission controls. Atmos Chem Phys. 2016;16(3):1603-18. doi:10.5194/acp-16-16032016.

33. Stadtler S, Kühn T, Schröder S, Taraborrelli D, Schultz MG, Kokkola H. Isoprene derived secondary organic aerosol in a global aerosol chemistry climate model. Geosci Model Dev Discuss. 2017;2017:1-35. doi:10.5194/gmd-2017-244.

34. Gordon H, Kirkby J, Baltensperger U, Bianchi F, Breitenlechner M, Curtius J et al. Causes and importance of new particle formation in the present-day and preindustrial atmospheres. Journal of Geophysical Research: Atmospheres. 2017;122(16):8739-60. doi:10.1002/2017jd026844.

35. Hodzic A, Jimenez JL. Modeling anthropogenically controlled secondary organic aerosols in a megacity: a simplified framework for global and climate models. Geosci Model Dev. 2011;4(4):901-17. doi:10.5194/gmd-4-901-2011.

36. Cubison MJ, Ortega AM, Hayes PL, Farmer DK, Day D, Lechner MJ et al. Effects of aging on organic aerosol from open biomass burning smoke in aircraft and laboratory studies. Atmos Chem Phys. 2011;11(23):12049-64. doi:10.5194/acp-11-12049-2011.

37. Schmidt GA, Kelley M, Nazarenko L, Ruedy R, Russell GL, Aleinov I et al. Configuration and assessment of the GISS ModelE2 contributions to the CMIP5 archive. Journal of Advances in Modeling Earth Systems. 2014;6(1):141-84. doi:10.1002/2013MS000265.

38. Taylor KE, Stouffer RJ, MeehI GA. An Overview of CMIP5 and the Experiment Design. Bulletin of the American Meteorological Society. 2012;93(4):485-98. doi:10.1175/bams-d-11-00094.1.

39. IPCC. Climate Change 2013: The Physical Science Basis. Contribution of Working Group I to the Fifth Assessment Report of the Intergovernmental Panel on Climate Change. Cambridge, United Kingdom and New York, NY, USA: Cambridge University Press; 2013.

40. Bellouin N, Rae J, Jones A, Johnson C, Haywood J, Boucher O. Aerosol forcing in the Climate Model Intercomparison Project (CMIP5) simulations by HadGEM2-ES and the role of ammonium nitrate. J Geophys Res-Atmos. 2011;116. doi:10.1029/2011jd016074.

41. Derwent RG, Jenkin ME, Johnson CE, Stevenson DS. The global distribution of secondary particulate matter in a 3-D Lagrangian chemistry transport model. Journal of Atmospheric Chemistry. 2003;44(1):5795.

42. Rotstayn LD, Jeffrey SJ, Collier MA, Dravitzki SM, Hirst AC, Syktus JI et al. Aerosol- and greenhouse gasinduced changes in summer rainfall and circulation in the Australasian region: a study using single-forcing climate simulations. Atmos Chem Phys. 2012;12(14):6377-404. doi:10.5194/acp-12-6377-2012.

43. Guenther A, Hewitt CN, Erickson D, Fall R, Geron C, Graedel T et al. A global model of natural volatile organic compound emissions. J Geophys Res-Atmos. 1995;100(D5):8873-92. doi:10.1029/94jd02950.

44. Takemura T, Okamoto H, Maruyama Y, Numaguti A, Higurashi A, Nakajima T. Global three-dimensional simulation of aerosol optical thickness distribution of various origins. J Geophys Res-Atmos. 2000;105(D14):17853-73. 
45. Watanabe S, Hajima T, Sudo K, Nagashima T, Takemura T, Okajima H et al. MIROC-ESM 2010: model description and basic results of CMIP5-20c3m experiments. Geosci Model Dev. 2011;4(4):845-72. doi:10.5194/gmd-4-845-2011.

46. Szopa S, Balkanski Y, Schulz M, Bekki S, Cugnet D, Fortems-Cheiney A et al. Aerosol and ozone changes as forcing for climate evolution between 1850 and 2100. Climate Dynamics. 2013;40(9-10):2223-50. doi:10.1007/s00382-012-1408-y.

47. Donner L, Wyman BL, Hemler RS, Horowitz LW, Ming Y, Zhao M et al. The Dynamical Core, Physical Parameterizations, and Basic Simulation Characteristics of the Atmospheric Component AM3 of the GFDL Global Coupled Model CM3. Journal of Climate. 2011;24(13):3484-519. doi:10.1175/2011jcli3955.1.

48. Tie X, Madronich S, Walters S, Edwards DP, Ginoux P, Mahowald N et al. Assessment of the global impact of aerosols on tropospheric oxidants. Journal of Geophysical Research: Atmospheres. 2005;110(D3). doi:10.1029/2004JD005359.

49. Miller RL, Schmidt GA, Nazarenko LS, Tausnev N, Bauer SE, DelGenio AD et al. CMIP5 historical simulations (1850-2012) with GISS ModelE2. Journal of Advances in Modeling Earth Systems. 2014. doi:10.1002/2013MS000266.

50. Nazarenko L, Schmidt GA, Miller RL, Tausnev N, Kelley M, Ruedy R et al. Future climate change under RCP emission scenarios with GISS ModelE2. Journal of Advances in Modeling Earth Systems. 2015;7(1):244-67. doi:10.1002/2014MS000403.

51. O'Donnell D, Tsigaridis K, Feichter J. Estimating the direct and indirect effects of secondary organic aerosols using ECHAM5-HAM. Atmos Chem Phys. 2011;11(16):8635-59. doi:10.5194/acp-11-8635-2011.

52. Lathière J, Hauglustaine DA, Friend AD, De Noblet-Ducoudre N, Viovy N, Folberth GA. Impact of climate variability and land use changes on global biogenic volatile organic compound emissions. Atmos Chem Phys. 2006;6:2129-46.

53. Lamarque JF, Bond TC, Eyring V, Granier C, Heil A, Klimont Z et al. Historical (1850-2000) gridded anthropogenic and biomass burning emissions of reactive gases and aerosols: methodology and application. Atmos Chem Phys. 2010;10(15):7017-39. doi:10.5194/acp-10-7017-2010.

54. Jokinen $T$, Berndt $T$, Makkonen $R$, Kerminen $V-M$, Junninen $H$, Paasonen $P$ et al. Production of extremely low volatile organic compounds from biogenic emissions: Measured yields and atmospheric implications. Proceedings of the National Academy of Sciences. 2015;112(23):7123-8. doi:10.1073/pnas.1423977112.

55. Lopez-Hilfiker FD, Mohr C, Ehn M, Rubach F, Kleist E, Wildt J et al. Phase partitioning and volatility of secondary organic aerosol components formed from $\alpha$-pinene ozonolysis and $\mathrm{OH}$ oxidation: the importance of accretion products and other low volatility compounds. Atmos Chem Phys. 2015;15(14):7765-76. doi:10.5194/acp-15-7765-2015.

56. Stark H, Yatavelli RLN, Thompson SL, Kang H, Krechmer JE, Kimmel JR et al. Impact of Thermal Decomposition on Thermal Desorption Instruments: Advantage of Thermogram Analysis for Quantifying Volatility Distributions of Organic Species. Environmental Science \& Technology. 2017;51(15):8491-500. doi:10.1021/acs.est.7b00160.

57. Hand JL, Malm WC. Review of aerosol mass scattering efficiencies from ground-based measurements since 1990. Journal of Geophysical Research: Atmospheres. 2007;112(D16). doi:10.1029/2007JD008484.

58. Seinfeld JH, Pandis SN. Atmospheric chemistry and physics - from air pollution to climate change. 2nd ed. New York: John Wiley \& Sons; 2006. 
59. Wu Y, Cheng T, Zheng L, Chen H. Sensitivity of mixing states on optical properties of fresh secondary organic carbon aerosols. Journal of Quantitative Spectroscopy and Radiative Transfer. 2017;195:147-55. doi:10.1016/j.jqsrt.2017.01.013.

60. Lack DA, Langridge JM, Bahreini R, Cappa CD, Middlebrook AM, Schwarz JP. Brown carbon and internal mixing in biomass burning particles. Proceedings of the National Academy of Sciences of the United States of America. 2012;109(37):14802-7. doi:10.1073/pnas.1206575109.

61. Chuang CC, Penner JE, Prospero JM, Grant KE, Rau GH, Kawamoto K. Cloud susceptibility and the first aerosol indirect forcing: Sensitivity to black carbon and aerosol concentrations. Journal of Geophysical Research: Atmospheres. 2002;107(D21):AAC 10-1-AAC -23. doi:10.1029/2000JD000215.

62. Makkonen R, Asmi A, Kerminen VM, Boy M, Arneth A, Guenther A et al. BVOC-aerosol-climate interactions in the global aerosol-climate model ECHAM5.5-HAM2. Atmos Chem Phys. 2012;12(21):10077-96. doi:10.5194/acp-12-10077-2012.

63. Scott CE, Rap A, Spracklen DV, Forster PM, Carslaw KS, Mann GW et al. The direct and indirect radiative effects of biogenic secondary organic aerosol. Atmos Chem Phys. 2014;14(1):447-70. doi:10.5194/acp-14447-2014.

64. D'Andrea SD, Acosta Navarro JC, Farina SC, Scott CE, Rap A, Farmer DK et al. Aerosol size distribution and radiative forcing response to anthropogenically driven historical changes in biogenic secondary organic aerosol formation. Atmos Chem Phys. 2015;15(5):2247-68. doi:10.5194/acp-15-2247-2015.

65. Kim H, Barkey B, Paulson SE. Real refractive indices of $\alpha$ - and $\beta$-pinene and toluene secondary organic aerosols generated from ozonolysis and photo-oxidation. Journal of Geophysical Research: Atmospheres. 2010;115(D24). doi:10.1029/2010JD014549.

66. Cappa CD, Che DL, Kessler SH, Kroll JH, Wilson KR. Variations in organic aerosol optical and hygroscopic properties upon heterogeneous $\mathrm{OH}$ oxidation. Journal of Geophysical Research: Atmospheres. 2011;116(D15). doi:10.1029/2011JD015918.

67. Harvey RM, Bateman AP, Jain S, Li YJ, Martin S, Petrucci GA. Optical Properties of Secondary Organic Aerosol from cis-3-Hexenol and cis-3-Hexenyl Acetate: Effect of Chemical Composition, Humidity, and Phase. Environmental Science \& Technology. 2016;50(10):4997-5006. doi:10.1021/acs.est.6b00625.

68. Li K, Wang W, Ge M, Li J, Wang D. Optical properties of secondary organic aerosols generated by photooxidation of aromatic hydrocarbons. 2014;4:4922. doi:10.1038/srep04922.

69. Hess M, Koepke P, Schult I. Optical Properties of Aerosols and Clouds: The Software Package OPAC. Bulletin of the American Meteorological Society. 1998;79(5):831-44. doi:10.1175/15200477(1998)079<0831:opoaac>2.0.co;2.

70. Ma X, Yu F, Luo G. Aerosol direct radiative forcing based on GEOS-Chem-APM and uncertainties. Atmos Chem Phys. 2012;12(12):5563-81. doi:10.5194/acp-12-5563-2012.

71. Aouizerats B, Thouron O, Tulet P, Mallet M, Gomes L, Henzing JS. Development of an online radiative module for the computation of aerosol optical properties in 3-D atmospheric models: validation during the EUCAARI campaign. Geosci Model Dev. 2010;3(2):553-64. doi:10.5194/gmd-3-553-2010.

72. Schulz $M$, Chin $M$, Kinne $S$. The aerosol model comparison project, AeroCom, phase II: clearing up diversity. IGAC newsletter. 2009;No. 41:2-11.

73. Yin CQ, Wang TJ, Solmon F, Mallet M, Jiang F, Li S et al. Assessment of direct radiative forcing due to secondary organic aerosol over China with a regional climate model. Tellus Series B-Chemical and Physical Meteorology. 2015;67. doi:10.3402/tellusb.v67.24634. 
74. Denjean C, Formenti P, Picquet-Varrault B, Camredon M, Pangui E, Zapf P et al. Aging of secondary organic aerosol generated from the ozonolysis of alpha-pinene: effects of ozone, light and temperature. Atmos Chem Phys. 2015;15(2):883-97. doi:10.5194/acp-15-883-2015.

75. Kim H, Paulson SE. Real refractive indices and volatility of secondary organic aerosol generated from photooxidation and ozonolysis of limonene, alpha-pinene and toluene. Atmos Chem Phys. 2013;13(15):7711-23. doi:10.5194/acp-13-7711-2013.

76. Sorooshian A, Shingler T, Crosbie E, Barth MC, Homeyer CR, Campuzano-Jost $P$ et al. Contrasting aerosol refractive index and hygroscopicity in the inflow and outflow of deep convective storms: Analysis of airborne data from DC3. J Geophys Res-Atmos. 2017;122(8):4565-77. doi:10.1002/2017jd026638.

77. Yu Y, Ezell MJ, Zelenyuk A, Imre D, Alexander L, Ortega J et al. Photooxidation of $\alpha$-pinene at high relative humidity in the presence of increasing concentrations of NOx. Atmos Environ. 2008;42(20):504460. doi:10.1016/j.atmosenv.2008.02.026.

78. Nakayama T, Sato K, Matsumi Y, Imamura T, Yamazaki A, Uchiyama A. Wavelength and NOx dependent complex refractive index of SOAs generated from the photooxidation of toluene. Atmos Chem Phys. 2013;13(2):531-45. doi:10.5194/acp-13-531-2013.

79. Kirchstetter TW, Novakov T, Hobbs PV. Evidence that the spectral dependence of light absorption by aerosols is affected by organic carbon. Journal of Geophysical Research: Atmospheres. 2004;109(D21). doi:10.1029/2004JD004999.

80. Sun HL, Biedermann L, Bond TC. Color of brown carbon: A model for ultraviolet and visible light absorption by organic carbon aerosol. Geophysical Research Letters. 2007;34(17). doi:10.1029/2007gl029797.

81. Wonaschutz A, Hitzenberger R, Bauer H, Pouresmaeil P, Klatzer B, Caseiro A et al. Application of the Integrating Sphere Method to Separate the Contributions of Brown and Black Carbon in Atmospheric Aerosols. Environmental Science \& Technology. 2009;43(4):1141-6. doi:10.1021/es8008503.

82. Bond TC, Bergstrom RW. Light absorption by carbonaceous particles: An investigative review. Aerosol Sci Technol. 2006;40(1):27-67. doi:doi 10.1080/02786820500421521.

83. Lack DA, Cappa CD. Impact of brown and clear carbon on light absorption enhancement, single scatter albedo and absorption wavelength dependence of black carbon. Atmos Chem Phys. 2010;10(9):4207-20. doi:10.5194/acp-10-4207-2010.

84. Bond TC, Habib G, Bergstrom RW. Limitations in the enhancement of visible light absorption due to mixing state. J Geophys Res-Atmos. 2006;111(D20). doi:10.1029/2006jd007315.

85. Laskin A, Laskin J, Nizkorodov SA. Chemistry of Atmospheric Brown Carbon. Chemical Reviews. 2015;115(10):4335-82. doi:10.1021/cr5006167.

86. De Haan DO, Corrigan AL, Tolbert MA, Jimenez JL, Wood SE, Turley JJ. Secondary Organic Aerosol Formation by Self-Reactions of Methylglyoxal and Glyoxal in Evaporating Droplets. Environmental Science \& Technology. 2009;43(21):8184-90. doi:10.1021/es902152t.

87. Sareen N, Moussa SG, McNeill VF. Photochemical Aging of Light-Absorbing Secondary Organic Aerosol Material. The Journal of Physical Chemistry A. 2013;117(14):2987-96. doi:10.1021/jp309413j.

88. Nozière B, Dziedzic $P$, Córdova A. Formation of secondary light-absorbing "fulvic-like" oligomers: A common process in aqueous and ionic atmospheric particles? Geophysical Research Letters. 2007;34(21). doi:10.1029/2007GL031300. 
89. Nozière B, Esteve W. Light-absorbing aldol condensation products in acidic aerosols: Spectra, kinetics, and contribution to the absorption index. Atmos Environ. 2007;41(6):1150-63. doi:10.1016/j.atmosenv.2006.10.001.

90. Shapiro EL, Szprengiel J, Sareen N, Jen CN, Giordano MR, McNeill VF. Light-absorbing secondary organic material formed by glyoxal in aqueous aerosol mimics. Atmos Chem Phys. 2009;9(7):2289-300. doi:10.5194/acp-9-2289-2009.

91. Ervens B, Turpin BJ, Weber RJ. Secondary organic aerosol formation in cloud droplets and aqueous particles (aqSOA): a review of laboratory, field and model studies. Atmos Chem Phys. 2011;11(21):11069102. doi:10.5194/acp-11-11069-2011.

92. Ervens B. Modeling the Processing of Aerosol and Trace Gases in Clouds and Fogs. Chemical Reviews. 2015;115(10):4157-98. doi:10.1021/cr5005887.

93. Woo JL, Kim DD, Schwier AN, Li R, McNeill VF. Aqueous aerosol SOA formation: impact on aerosol physical properties. Faraday Discussions. 2013;165(0):357-67. doi:10.1039/C3FD00032J.

94. Carlton AG, Turpin BJ, Altieri KE, Seitzinger SP, Mathur R, Roselle SJ et al. CMAQ Model Performance Enhanced When In-Cloud Secondary Organic Aerosol is Included: Comparisons of Organic Carbon Predictions with Measurements. Environmental Science \& Technology. 2008;42(23):8798-802. doi:10.1021/es801192n.

95. Wagner NL, Brock CA, Angevine WM, Beyersdorf A, Campuzano-Jost P, Day D et al. In situ vertical profiles of aerosol extinction, mass, and composition over the southeast United States during SENEX and SEAC ${ }^{4} R S$ : observations of a modest aerosol enhancement aloft. Atmos Chem Phys. 2015;15(12):7085-102. doi:10.5194/acp-15-7085-2015.

96. Lee HJ, Aiona PK, Laskin A, Laskin J, Nizkorodov SA. Effect of Solar Radiation on the Optical Properties and Molecular Composition of Laboratory Proxies of Atmospheric Brown Carbon. Environmental Science \& Technology. 2014;48(17):10217-26. doi:10.1021/es502515r.

97. Zhao R, Lee AKY, Huang L, Li X, Yang F, Abbatt JPD. Photochemical processing of aqueous atmospheric brown carbon. Atmos Chem Phys. 2015;15(11):6087-100. doi:10.5194/acp-15-6087-2015.

98. Zhong $M$, Jang M. Dynamic light absorption of biomass-burning organic carbon photochemically aged under natural sunlight. Atmos Chem Phys. 2014;14(3):1517-25. doi:10.5194/acp-14-1517-2014.

99. Forrister H, Liu J, Scheuer E, Dibb J, Ziemba L, Thornhill KL et al. Evolution of brown carbon in wildfire plumes. Geophysical Research Letters. 2015;42(11):4623-30. doi:10.1002/2015gl063897.

100. De Haan DO, Hawkins LN, Welsh HG, Pednekar R, Casar JR, Pennington EA et al. Brown Carbon Production in Ammonium- or Amine-Containing Aerosol Particles by Reactive Uptake of Methylglyoxal and Photolytic Cloud Cycling. Environmental Science \& Technology. 2017;51(13):7458-66. doi:10.1021/acs.est.7b00159.

101. Laskin J, Laskin A, Roach PJ, Slysz GW, Anderson GA, Nizkorodov SA et al. High-Resolution Desorption Electrospray lonization Mass Spectrometry for Chemical Characterization of Organic Aerosols. Analytical Chemistry. 2010;82(5):2048-58. doi:10.1021/ac902801f.

102. Updyke KM, Nguyen TB, Nizkorodov SA. Formation of brown carbon via reactions of ammonia with secondary organic aerosols from biogenic and anthropogenic precursors. Atmos Environ. 2012;63:22-31. doi:10.1016/j.atmosenv.2012.09.012. 
103. Phillips SM, Bellcross AD, Smith GD. Light Absorption by Brown Carbon in the Southeastern United States is pH-dependent. Environmental Science \& Technology. 2017;51(12):6782-90. doi:10.1021/acs.est.7b01116.

104. Alexander DTL, Crozier PA, Anderson JR. Brown carbon spheres in East Asian outflow and their optical properties. Science. 2008;321(5890):833-6. doi:10.1126/science.1155296.

105. Lukacs H, Gelencser A, Hammer S, Puxbaum H, Pio C, Legrand M et al. Seasonal trends and possible sources of brown carbon based on 2-year aerosol measurements at six sites in Europe. J Geophys ResAtmos. 2007;112(D23). doi:10.1029/2006jd008151.

106. Washenfelder RA, Attwood AR, Brock CA, Guo H, Xu L, Weber RJ et al. Biomass burning dominates brown carbon absorption in the rural southeastern United States. Geophysical Research Letters. 2015;42(2):653-64. doi:10.1002/2014GL062444.

107. Cheng Y, He KB, Zheng M, Duan FK, Du ZY, Ma YL et al. Mass absorption efficiency of elemental carbon and water-soluble organic carbon in Beijing, China. Atmos Chem Phys. 2011;11(22):11497-510. doi:10.5194/acp-11-11497-2011.

108. Zhang XL, Lin YH, Surratt JD, Zotter P, Prevot ASH, Weber RJ. Light-absorbing soluble organic aerosol in Los Angeles and Atlanta: A contrast in secondary organic aerosol. Geophysical Research Letters. 2011;38. doi:10.1029/2011gl049385.

109. Hecobian A, Zhang X, Zheng M, Frank N, Edgerton ES, Weber RJ. Water-Soluble Organic Aerosol material and the light-absorption characteristics of aqueous extracts measured over the Southeastern United States. Atmos Chem Phys. 2010;10(13):5965-77. doi:10.5194/acp-10-5965-2010.

110. Andreae MO, Gelencser A. Black carbon or brown carbon? The nature of light-absorbing carbonaceous aerosols. Atmos Chem Phys. 2006;6:3131-48.

111. Bluvshtein N, Lin P, Flores JM, Segev L, Mazar Y, Tas E et al. Broadband optical properties of biomassburning aerosol and identification of brown carbon chromophores. Journal of Geophysical Research: Atmospheres. 2017;122(10):5441-56. doi:10.1002/2016JD026230.

112. Pokhrel RP, Beamesderfer ER, Wagner NL, Langridge JM, Lack DA, Jayarathne T et al. Relative importance of black carbon, brown carbon, and absorption enhancement from clear coatings in biomass burning emissions. Atmos Chem Phys. 2017;17(8):5063-78. doi:10.5194/acp-17-5063-2017.

113. Hoffer A, Tóth Á, Pósfai M, Chung CE, Gelencsér A. Brown carbon absorption in the red and nearinfrared spectral region. Atmos Meas Tech. 2017;10(6):2353-9. doi:10.5194/amt-10-2353-2017.

114. Moosmuller H, Chakrabarty RK, Arnott WP. Aerosol light absorption and its measurement: A review. J Quant Spectrosc Radiat Transf. 2009;110(11):844-78. doi:10.1016/j.jqsrt.2009.02.035.

115. Park RJ, Kim MJ, Jeong JI, Youn D, Kim S. A contribution of brown carbon aerosol to the aerosol light absorption and its radiative forcing in East Asia. Atmos Environ. 2010;44(11):1414-21. doi:10.1016/j.atmosenv.2010.01.042.

116. Lin G, Penner JE, Flanner MG, Sillman S, Xu L, Zhou C. Radiative forcing of organic aerosol in the atmosphere and on snow: Effects of SOA and brown carbon. Journal of Geophysical Research: Atmospheres. 2014;119(12):7453-76. doi:10.1002/2013JD021186.

117. Chen Y, Bond TC. Light absorption by organic carbon from wood combustion. Atmos Chem Phys. 2010;10(4):1773-87. doi:10.5194/acp-10-1773-2010. 
118. Bahadur R, Praveen PS, Xu Y, Ramanathan V. Solar absorption by elemental and brown carbon determined from spectral observations. Proceedings of the National Academy of Sciences. 2012;109(43):17366-71. doi:10.1073/pnas.1205910109.

119. Cheng Y, He K-b, Engling G, Weber R, Liu J-m, Du Z-y et al. Brown and black carbon in Beijing aerosol: Implications for the effects of brown coating on light absorption by black carbon. Science of The Total Environment. 2017;599:1047-55. doi:10.1016/j.scitotenv.2017.05.061.

120. Paredes-Miranda G, Arnott WP, Jimenez JL, Aiken AC, Gaffney JS, Marley NA. Primary and secondary contributions to aerosol light scattering and absorption in Mexico City during the MILAGRO 2006 campaign. Atmos Chem Phys. 2009;9(11):3721-30. doi:10.5194/acp-9-3721-2009.

121. Epstein SA, Riipinen I, Donahue NM. A Semiempirical Correlation between Enthalpy of Vaporization and Saturation Concentration for Organic Aerosol. Environmental Science \& Technology. 2010;44(2):7438. doi:10.1021/es902497z.

122. Tao Y, McMurry PH. Vapor pressures and surface free energies of C14-C18 monocarboxylic acids and C5 and C6 dicarboxylic acids. Environmental Science \& Technology. 1989;23(12):1519-23. doi:10.1021/es00070a011.

123. Bilde M, Pandis SN. Evaporation Rates and Vapor Pressures of Individual Aerosol Species Formed in the Atmospheric Oxidation of $\alpha$ - and $\beta$-Pinene. Environmental Science \& Technology. 2001;35(16):33449. doi:10.1021/es001946b.

124. Stanier CO, Donahue NM, Pandis SN. Parameterization of secondary organic aerosol mass fractions from smog chamber data. Atmos Environ. 2008;42(10):2276-99. doi:10.1016/j.atmosenv.2007.12.042.

125. Bian F, Bowman FM. Theoretical Method for Lumping Multicomponent Secondary Organic Aerosol Mixtures. Environmental Science \& Technology. 2002;36(11):2491-7. doi:10.1021/es015600s.

126. Bian F, Bowman FM. A lumping model for composition- and temperature-dependent partitioning of secondary organic aerosols. Atmos Environ. 2005;39(7):1263-74. doi:10.1016/j.atmosenv.2004.10.044.

127. Samset BH, Myhre G, Schulz M, Balkanski Y, Bauer S, Berntsen TK et al. Black carbon vertical profiles strongly affect its radiative forcing uncertainty. Atmos Chem Phys. 2013;13(5):2423-34. doi:10.5194/acp13-2423-2013.

128. Tsigaridis K. Study of the organic aerosols in the atmosphere and their impact on climate, with the use of three-dimensional global models. Heraklion, Greece: University of Crete; 2003.

129. Andreae MO, Afchine A, Albrecht R, Holanda BA, Artaxo P, Barbosa HMJ et al. Aerosol characteristics and particle production in the upper troposphere over the Amazon Basin. Atmos Chem Phys Discuss. 2017;2017:1-95. doi:10.5194/acp-2017-694.

130. Shrivastava M, Zhao C, Easter RC, Qian Y, Zelenyuk A, Fast JD et al. Sensitivity analysis of simulated SOA loadings using a variance-based statistical approach. Journal of Advances in Modeling Earth Systems. 2016;8(2):499-519. doi:10.1002/2015MS000554.

131. Marvel K, Schmidt GA, Shindell D, Bonfils C, LeGrande AN, Nazarenko L et al. Do responses to different anthropogenic forcings add linearly in climate models? Environmental Research Letters. 2015;10(10):104010.

132. Arneth A, Harrison SP, Zaehle S, Tsigaridis K, Menon S, Bartlein PJ et al. Terrestrial biogeochemical feedbacks in the climate system. Nature Geoscience. 2010;3(8):525-32. doi:10.1038/ngeo905. 
133. Carslaw KS, Boucher O, Spracklen DV, Mann GW, Rae JGL, Woodward S et al. A review of natural aerosol interactions and feedbacks within the Earth system. Atmos Chem Phys. 2010;10(4):1701-37.

134. Carslaw KS, Lee LA, Reddington CL, Pringle KJ, Rap A, Forster PM et al. Large contribution of natural aerosols to uncertainty in indirect forcing. Nature. 2013;503(7474):67-71. doi:10.1038/nature12674.

135. Jacobson MZ. Isolating nitrated and aromatic aerosols and nitrated aromatic gases as sources of ultraviolet light absorption. J Geophys Res-Atmos. 1999;104(D3):3527-42. doi:10.1029/1998jd100054.

136. Jacobson MZ. Control of fossil-fuel particulate black carbon and organic matter, possibly the most effective method of slowing global warming. J Geophys Res-Atmos. 2002;107(D19). doi:10.1029/2001jd001376.

137. Zhang Y, Forrister H, Liu J, Dibb J, Anderson B, Schwarz JP et al. Top-of-atmosphere radiative forcing affected by brown carbon in the upper troposphere. Nature Geosci. 2017;10(7):486-9. doi:10.1038/ngeo2960.

138. Haywood JM, Shine KP. Multi-spectral calculations of the direct radiative forcing of tropospheric sulphate and soot aerosols using a column model. Q J R Meteorol Soc. 1997;123(543):1907-30. doi:10.1002/qj.49712354307.

139. Zarzycki CM, Bond TC. How much can the vertical distribution of black carbon affect its global direct radiative forcing? Geophysical Research Letters. 2010;37(20). doi:10.1029/2010GL044555.

140. Jathar SH, Farina SC, Robinson AL, Adams PJ. The influence of semi-volatile and reactive primary emissions on the abundance and properties of global organic aerosol. Atmos Chem Phys. 2011;11(15):7727-46. doi:10.5194/acp-11-7727-2011.

141. Donahue NM, Robinson AL, Stanier CO, Pandis SN. Coupled partitioning, dilution, and chemical aging of semivolatile organics. Environmental Science \& Technology. 2006;40(8):2635-43. doi:10.1021/es052297c.

142. Myhre G, Samset BH, Schulz M, Balkanski Y, Bauer S, Berntsen TK et al. Radiative forcing of the direct aerosol effect from AeroCom Phase II simulations. Atmos Chem Phys. 2013;13(4):1853-77. doi:10.5194/acp-13-1853-2013.

143. Carlton AG, Pinder RW, Bhave PV, Pouliot GA. To What Extent Can Biogenic SOA be Controlled? Environmental Science \& Technology. 2010;44(9):3376-80. doi:10.1021/es903506b.

144. Jo DS, Park RJ, Lee S, Kim S-W, Zhang X. A global simulation of brown carbon: implications for photochemistry and direct radiative effect. Atmos Chem Phys. 2016;16(5):3413-32. doi:10.5194/acp-163413-2016.

145. Heald CL, Henze DK, Horowitz LW, Feddema J, Lamarque JF, Guenther A et al. Predicted change in global secondary organic aerosol concentrations in response to future climate, emissions, and land use change. Journal of Geophysical Research: Atmospheres. 2008;113(D5):D05211. doi:10.1029/2007JD009092.

146. Liao $\mathrm{H}$, Chen $\mathrm{W}-\mathrm{T}$, Seinfeld $\mathrm{JH}$. Role of climate change in global predictions of future tropospheric ozone and aerosols. Journal of Geophysical Research: Atmospheres. 2006;111(D12). doi:10.1029/2005JD006852.

147. Pfister GG, Hess PG, Emmons LK, Rasch PJ, Vitt FM. Impact of the summer 2004 Alaska fires on top of the atmosphere clear-sky radiation fluxes. Journal of Geophysical Research: Atmospheres. 2008;113(D2). doi:10.1029/2007JD008797. 
148. Ji Z, Kang S, Cong Z, Zhang Q, Yao T. Simulation of carbonaceous aerosols over the Third Pole and adjacent regions: distribution, transportation, deposition, and climatic effects. Climate Dynamics. 2015;45(9):2831-46. doi:10.1007/s00382-015-2509-1.

149. Ghan SJ, Liu X, Easter RC, Zaveri R, Rasch PJ, Yoon J-H et al. Toward a Minimal Representation of Aerosols in Climate Models: Comparative Decomposition of Aerosol Direct, Semidirect, and Indirect Radiative Forcing. Journal of Climate. 2012;25(19):6461-76. doi:10.1175/jcli-d-11-00650.1.

150. Boucher O. Atmospheric Aerosols: Properties and Climate Impacts. Springer; 2015.

151. Lin G, Sillman S, Penner JE, Ito A. Global modeling of SOA: the use of different mechanisms for aqueous-phase formation. Atmos Chem Phys. 2014;14(11):5451-75. doi:10.5194/acp-14-5451-2014.

152. Liu J, Horowitz LW, Fan S, Carlton AG, Levy H. Global in-cloud production of secondary organic aerosols: Implementation of a detailed chemical mechanism in the GFDL atmospheric model AM3. Journal of Geophysical Research: Atmospheres. 2012;117(D15):n/a-n/a. doi:10.1029/2012JD017838.

153. He C, Liu J, Carlton AG, Fan S, Horowitz LW, Levy li H et al. Evaluation of factors controlling global secondary organic aerosol production from cloud processes. Atmos Chem Phys. 2013;13(4):1913-26. doi:10.5194/acp-13-1913-2013.

154. Wang X, Heald CL, Liu J, Weber RJ, Campuzano-Jost P, Jimenez JL et al. Exploring the observational constraints on the simulation of brown carbon. Atmos Chem Phys. 2018;18(2):635-53. doi:10.5194/acp18-635-2018.

155. Seland $\varnothing$, Iversen T, Kirkevåg A, Storelvmo T. Aerosol-climate interactions in the CAM-Oslo atmospheric GCM and investigation of associated basic shortcomings. Tellus Series a-Dynamic Meteorology and Oceanography. 2008;60(3):459-91. doi:10.1111/j.1600-0870.2008.00318.x.

156. Chin M, DiehI T, Dubovik O, Eck TF, Holben BN, Sinyuk A et al. Light absorption by pollution, dust, and biomass burning aerosols: a global model study and evaluation with AERONET measurements. Annales Geophysicae. 2009;27(9):3439-64.

157. Stier P, Seinfeld JH, Kinne S, Boucher O. Aerosol absorption and radiative forcing. Atmos Chem Phys. 2007;7(19):5237-61. doi:10.5194/acp-7-5237-2007. 


\section{Tables}

Table 1 Refractive indices of OA at $550 \mathrm{~nm}$ used in selected models. Unless $\mathrm{BrC}$ is explicitly simulated, POA and SOA are assumed to have the same refractive index, except for one model. Data from the references listed and from AeroCom (https://wiki.met.no/aerocom/optical_properties).

\begin{tabular}{lll}
\hline Model & Refractive index & Reference \\
\hline BCC & $1.53-0.0059 i$ & \\
CAM4-Oslo & $1.53-0.006 i$ & {$[155]$} \\
CAM5-MAM3 & $1.53-0.005665 i$ & \\
GEOS-Chem & $1.53-0.008 i$ (insoluble) & {$[69]$} \\
& $1.53-0.006 i$ (soluble) & \\
GEOS-Chem-APM & $1.45-0.001 i$ & {$[71,70]$} \\
GISS ModelE & $1.527-0.014 i$ & \\
GMI & $1.53-0.006 i$ & {$[156]$} \\
GOCART & $1.53-0.006 i$ & {$[156]$} \\
HADGEM2-ES & $1.54-0.006 i$ (fossil fuel) & {$[40]$} \\
& $1.43-0.0 i$ (SOA) & \\
MPIHAM & $1.53-0.008 i$ (insoluble) & {$[69,157]$} \\
& $1.53-0.006 i$ (soluble) & \\
SPRINTARS & $1.53-0.006 i$ & \\
TM5 & $1.53-0.0055 i$ & \\
\hline
\end{tabular}


Figures, created with IDL
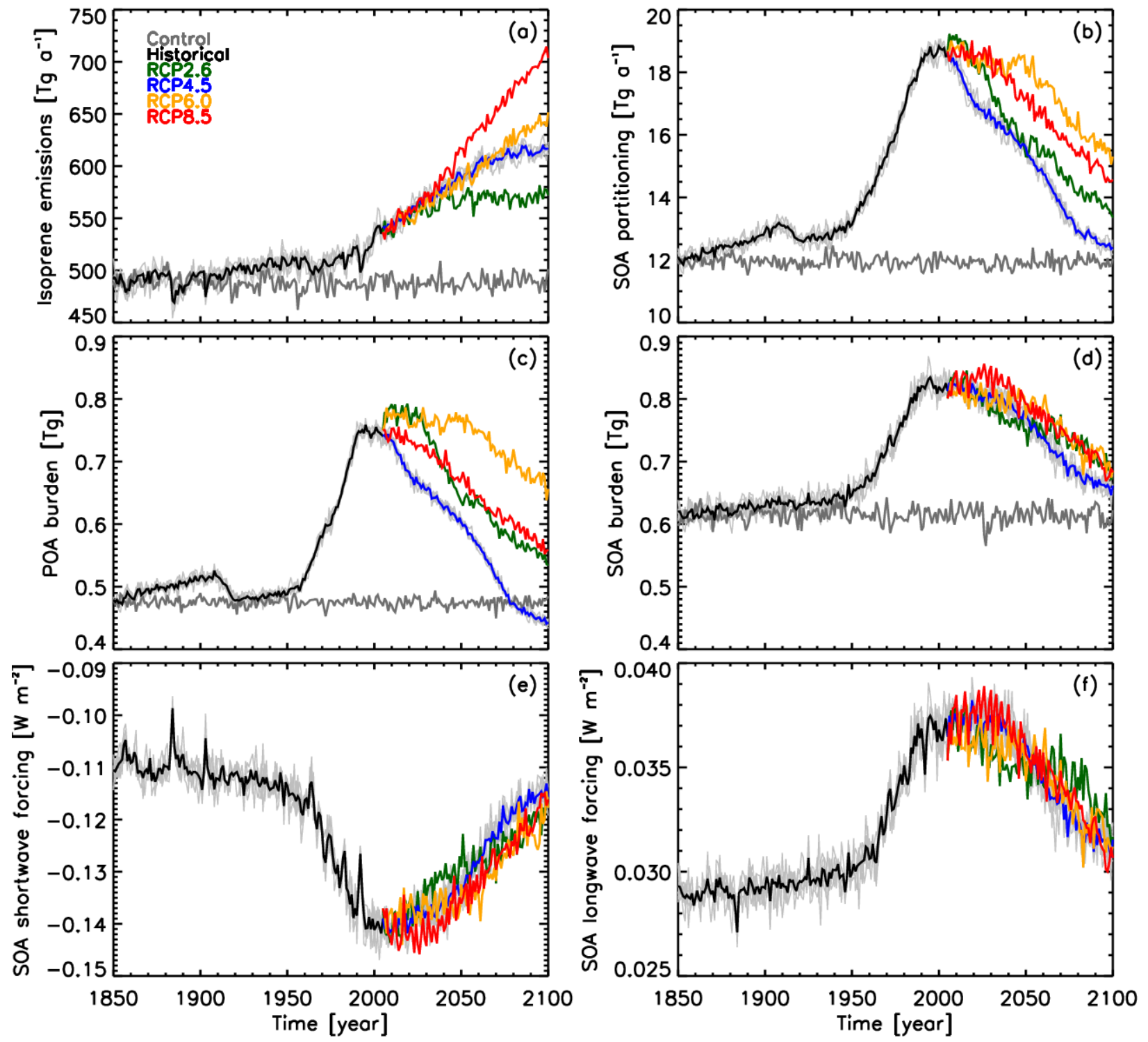

Fig. 1 GISS-E2-R model simulations of isoprene emissions (a), SOA formation due to partitioning of semivolatile gases (b), POA (c) and SOA (d) burden, and SOA shortwave (e) and longwave (f) forcing. The plots present the historical period (1850-2005; black), the 4 RCP CMIP5 scenarios (2006-2100; RCP2.6: green; RCP4.5: blue; RCP6.0: orange; RCP8.5: red), and the first 250 years of the preindustrial control (dark grey). Also shown the 5 ensemble members for the historical period and RCP4.5 (light grey) 